\title{
The "Northern Caddoan Area" was not Caddoan
}

Frank F. Schambach

Follow this and additional works at: https://scholarworks.sfasu.edu/ita

Part of the American Material Culture Commons, Archaeological Anthropology Commons, Environmental Studies Commons, Other American Studies Commons, Other Arts and Humanities Commons, Other History of Art, Architecture, and Archaeology Commons, and the United States History Commons

Tell us how this article helped you.

This Article is brought to you for free and open access by the Center for Regional Heritage Research at SFA ScholarWorks. It has been accepted for inclusion in Index of Texas Archaeology: Open Access Gray Literature from the Lone Star State by an authorized editor of SFA ScholarWorks. For more information, please contact cdsscholarworks@sfasu.edu. 


\section{The "Northern Caddoan Area" was not Caddoan \\ Creative Commons License \\ (c) $($ ) $(9)$}

This work is licensed under a Creative Commons Attribution-NonCommercial 4.0 International License 


\title{
The "Northern Caddoan Area" was not Caddoan
}

\author{
Frank F. Schambach \\ Introduction
}

\begin{abstract}
If I were laboring in the Caddoan vineyard, I would stress the individuality of Caddoan culture, its independence of, not to say resistance to, the spread of Mississippian culture
\end{abstract}

\section{Philip Phillips}

In this paper I will challenge one of the major unexamined assumptions in the archeology of Eastern North America, the assumption that the Arkansas River Valley and Ozark Highland regions of eastern Oklahoma and western Arkansas, the so-called northern Caddoan Area, was the home of Caddo people who were closely related culturally and linguistically to the Caddo people of southwest Arkansas, northwest Louisiana, east Texas, and southeast Oklahoma. I will propose, instead, that the archeology of this locality is much more complex and interesting than the conventional wisdom would have it. What is involved here, I suggest, is not one region but parts of three, with three culturally and biologically distinct populations. Furthermore, I will propose that Spiro, the key site in this locality, is actually two sites, one Caddoan, the other Mississippian.

\section{Northern Caddoan Area}

The concept of a northern (or Arkansas Valley) Caddoan culture, with Spiro as its apogee, has been embedded in the literature since 1946 when Kenneth Orr identified Spiro as a Caddo site. He did so on the grounds that it was within the region that John R. Swanton had identified as the "Caddoan archaeological area". certainly on very little evidence, in an unpublished paper written in 1932 (Orr 1946). Since then, the concept has been kept alive partly by the presence of a few Caddo pots of a few types, most of them probably trade wares, at sites such as Harlan and Spiro, and partly by the halo effect of the Spiro site. Spiro, with its spectacular hoards, its romantic history, and its reputation as "the principal and most famous site in the Caddoan area" (Brown 1984a:241) has come to exemplify Caddo Area archeology in the minds of all but a few regional specialists who know the Spiro phase Spiro has no parallels in the Caddo Area.

It is clear, I think, that this concept is not well founded, and some regional specialists seem to be backing away from it. Indeed, the recent introduction of the terms "Northern Caddoan Area" and "Arkansas Valley Caddoan" seems to be a step in this direction. Robert E. Bell (1972:259-260, 1984:239) pointed out almost twenty years ago that there are basic differences between the archeology of this locality and that of the so-called "southern Caddo Area" of southwest Arkansas, northwest Louisiana, northeast Texas, and southeast Oklahoma, the area that I would call the real Caddo Area. Another step in this direction is James Brown's (1984b:55-56) recent observation that Spiro and the Ozark Highland sites are much closer to each other culturally than either is to the "Southern Caddo Area", and that while "Spiro is not usually considered as representative of a marginal tradition"..., i.e., the Ozark Highland tradition as opposed to the Caddo tradition,..." a good case could be made for it being so." I agree, except I think the situation is a bit more complex than Brown perceives it, a point I will return to shortly. 
The differences between the two traditions (pointed out repeatedly by Bell $1972: 259-260 ; 1984: 239)$ include differences in house types, subsistence techniques, storage techniques, mortuary ceremonialism, burial patterns, social organization, art styles, mound types, and pottery. The meaning of these diferences is that the Arkansas Valley and Ozark Highland peoples, with their square wattle and daub houses, their mortuaries, their stone hoes, and their mostly plain shell-tempered pottery, were Mississippians, while the Caddo were Gulf Tradition people, linguistically and biologically distinct, who were slow to adopt Mississippian traits.

The basic flaw in the Northern Caddo Area concept is that no one has looked closely at the uniquely complex biogeography of this area, which actually comprises parts of three biogeographical regions. One is the Ozark Highlands, with a distinct but, as yet, inadequately conceptualized upland Mississippian tradition that includes, from A.D. 900 on, the closely related Harlan, Huntsville, and Loftin phases of northeast Oklahoma, northwest Arkansas, and southwest Mlssouri.

The second region is the Arkansas Valley, the Arkansas Valley proper, not the "Arkansas Basin" or the "Arkansas River Drainage", vague terms that appear (but are not defined) in the recent literature (Rogers 1989; Brown et al. 1978). The Arkansas Valley is a clearly defined strip of Southeastern floodplain forest that once extended into eastern Oklahoma as far west as the Forks of the Arkansas (Brown et al. 1978:174 and Figure 7.1). This was a Lower Mississippi Valley environment that from time to time harbored Lower Mississippi Valley people, real Mississippians, Mississippian frontiersmen who, I suspect, moved west or east in the Arkansas Valley in response to changes in climate and politics. Among them were people of the Plum Bayou culture (Rolingson 1988; Brown 1984b:12-14), and of the Spiro phase. The latter people, I have suggested (1988), were Mississippian traders who had positioned themselves to supply buffalo meat and hides to the rapidly growing and increasingly protein poor and clothing poor Mississippian populations of eastern Arkansas and beyond.

The third region is the Ouachita Mountain region, south of the Arkansas Valley, the home of the northernmost Caddo people. These people were the source of the Caddo pottery, and probably other traits, that diffused to sites in the Arkansas Valley and the Ozark Highlands.

This more complex and, I think, more realistic model of the cultural and biogeographical situation in northwest Arkansas and northeast Oklahoma during the Mississippi Period permits important modifications in our understanding of the nature and culture history of the Spiro site. The first is that Spiro is not one site, as everyone has assumed, but two culturally and temporally distinct sites. One is the Brown mound group located on the first terrace above the Arkansas floodplain, the other the Craig mound and its associated village area down on the floodplain.

I suggest that the Caddo built the Brown mound group during the early Mississippi period when there were no Mississippians in the vicinity. It has all the characteristics of a Caddo ceremonial center, from the pottery, to the burned house mounds, to the possible but still unexplored early Caddo shaft grave in the Brown mound, to the subsistence patterns revealed in recently reported work on the Copple Mound, patterns that Gayle Fritz (1989:86) finds distinctly non-Mississippian, and that I find plausibly early Caddoan.

In my opinion, the Brown Mound group is the northernmost Caddo ceremonial center. The people who built it were Caddo people of a still undefined regional phase. They were not, as present interpretations would have it, a Harlan phase people. The identification of 
the Brown Mound group as a Harlan phase site is the keystone in the Northern Caddo Area concept. It is the only link between the Spiro locality and the Ozark Highlands, yet it is based on the flimsiest of evidence.

Thus, on the one hand, the only shared traits between the Brown Mound group and the Harlan site, the type site of the Harlan phase, are superficial ones: Alba projectile points and the pottery types Crockett Curvilinear Incised and Spiro Engraved. These traits occurred throughout the Caddo Area and well beyond its borders in the early Mississippi period, and Bell has always maintained that the small number of Crockett and Spiro vessels at Harlan were the result of trade.

On the other hand, the differences between the two sites (which are $130 \mathrm{~km}$ apart) are basic. The small mounds in the Brown mound group cover the remains of structures containing abundant domestic debris. These are "burned house mounds" of the type found throughout the Caddo Area. But at the Harlan site all the mounds covered the remains of scrupulously cleaned mortuaries, structures that lacked domestic debris (Bell 1972:261, 1984:229-231; Phillips and Brown 1978:12). These mortuaries, which appear to be characteristic of centers in the upland Mississippian tradition sites of the Ozark Highlands, do not appear in the Caddo Area.

Furthermore, Woodward Plain, the shell-tempered pottery type that dominates the assemblage at Harlan (Bell 1972:247) is virtually absent at the Brown Mound group where shell-tempered pottery amounts to only a fraction of one percent of the recorded ceramics, rather than the substantial percentage (certainly more than 50 percent) that should be there if the Brown Mound group had a Harlan phase component. Clearly it does not. There were early Caddo people at Brown but not at Harlan. Once its bogus connection with Spiro is severed, it is apparent that the Harlan phase, with its Ozark Highlands distribution, its mortuaries, its square, four support post houses, its plain, shelltempered pottery, its hoe technology, and its corn agriculture (Brown 1984b:16), is a Mississippian manifestation. It is quite unlike anything in the Caddo Area, the area south of Spiro, where none of these traits existed in the period A.D. 950-1250.

The Caddo, I would suggest, withdrew from the Brown Mound group prior to the Spiro phase when Mississippians moved up the Arkansas Valley and built a small village and the distinctly non-Caddoan Craig Mound 1200 feet east of the Brown Mound group. At the end of the Spiro phase the Mississippians, who were probably ancestral Tunica, withdrew down the Arkansas Valley to south of Dardenelle, where De Soto encountered them in 1541. The Caddo then returned to the Spiro locality, an occupation recognized as the Fort Coffee phase.

What, if any, relationship was there between the Spiro phase Mississippians at Spiro and the Mississippians of the Ozark Highlands? The central idea in the Northern Caddoan Area concept has been that Spiro, because it was Spiro, dominated both the Arkansas Valley and the Ozark Highlands throughout the Mississippi Period (e.g., Kay et al. 1989:132 and Figure 41). There is, as I have indicated, no good evidence for this during the Harlan phase and during the Spiro phase there is none at all. Considering the rugged terrain (no one ever seems to mention that the Boston Mountains lie between Spiro and all of its alleged subsidiary centers in the Ozark Highlands) and the distances involved $(130$ to $150 \mathrm{~km})$ from Spiro to these centers, what kind of influence or contact could have been maintained, and for what reasons? I do not wish to revive the myth of Ozark Highlands marginality, but I would suggest that the Mississippians in the Ozark Highlands had little to do with the Mississippians or the Caddoans at Spiro. 


\section{Note}

This paper was originally presented at the 55th Annual Meeting of the Society for American Archaeology, April 22, 1990, Las Vegas, Nevada.

\section{References Cited}

Bell, Robert E.

1972 The Harlan Site, Ck-6. A Prehistoric Mound Center in Cherokee

County, Eastern Oklahoma. Memoir No. 2. Oklahoma Anthropological Society.

1984 Arkansas Valley Caddoan: The Harlan Phase. In Prehistory of Oklahoma, edited by Robert E. Bell, pp. 221-240. Academic Press, New York.

Brown, James $A$.

1984a Arkansas Valley Caddoan: The Spiro Phase. In Prehistory of Oklahoma, edited by Robert E. Bell, pp. 241-263. Academic Press, New York.

1984b Prehistoric Southern Ozark Marginality: A Myth Exposed. Missouri Archaeological Society, Special Publication No. 6. Columbia.

Brown, James A., Robert E. Bell, and Don G. Wyckoff

1978 Caddoan Settlement Patterns in the Arkansas River Drainage. In Mississippian Settlement Patterns, edited by Bruce D. Smith. Academic Press, New York.

Fritz, Gayle J.

1989 Evidence of Plant Use from Copple Mound at the Spiro Site. In Contributions to Spiro Archeology: Mound Excavations and Regional Perspectives, edited by J. Daniel Rogers, Don G. Wyckoff, and Dennis A. Peterson, pp. 65-86. Oklahoma Archeological Survey, Studies in Oklahoma's Past, No. 16. Norman.

Kay, Marvin, George Sabo III, and Ralph Merletti 1989 Late Prehistoric Settlement Patterning: A View from Three Caddoan CivicCeremonial Centers in Northwest Arkansas. In Contributions to Spiro Archeology: Mound Excavations and Regional Perspectives, edited by J. Daniel Rogers, Don G. Wyckoff, and Dennis A. Peterson, pp. 129-157. Oklahoma Archeological Survey, Studies in Oklahoma's Past, No. 16. Norman.

Orr, Kenneth G.

1946 The Archaeological Situation at Spiro, Oklahoma: A Preliminary Report. American Antiquity 11:228-256.

Phillips, Philip and James A. Brown 1978 Pre-Columbian Shell Engravings from the Craig Mound at Spiro, Oklahoma. Peabody Museum of Archaeology and Ethnology, Harvard University, Paperback Edition, Part I. Cambridge. 
Rogers, J. Daniel

1989 Settlement Contexts for Shifting Authority in the Arkansas Basin. In Contributions to Spiro Archeology: Mound Excavations and Regional Perspectives, edited by J. Daniel Rogers, Don G. Wyckoff, and Dennis A. Peterson, pp. 159-176. Oklahoma Archeological Survey, Studies in Oklahoma's Past, No. 16. Norman.

Rolingson, Martha Ann

1988 The Coles Creek Period in the Arkansas River Lowland. Paper presented at the symposium Coles Creek and its Neighbors, Southeastern Archaeological Conference, New Orleans.

Schambach, Frank

1988 The Archaeology of OKlahoma. Quarterly Review of Archaeology, Volume 9, No. 4, pp. 5-9.

\title{
Northeast Texas Historic Contexts
}

Work progresses on the development of Historic Contexts for the Northeast Texas region of the Texas State Plan. Final drafts of two Historic Contexts, both directly pertinent to Caddoan archaeological research efforts, were recently submitted to the Texas Historical Commission, Department of Archeological Planning and Review:

\section{Cultural Implications of Late Quaternary Environmental Change in Northeast Texas}

Michael B. Collins and C. Britt Bousman

Texas Archeological Research Laboratory University of Texas at Austin 1990 vii $+134 \mathrm{pp}$.

Historic Context: The Evolution of Agricultural Societies in Northeast Texas before A.D. 1600

Part I: The Development of Agricultural Subsistence, Regional and Diachronic Variability in Caddoan Subsistence, and Implications for the Caddoan Archaeological Record

\author{
Part II: Faunal and Paleobotanical Data \\ from the Caddoan Area \\ Timothy K. Perttula \\ Texas Historical Commission \\ $1990 \mathrm{vii}+439 \mathrm{pp}$.
}

Ross Fields and Steve Tomka (Prewitt and Associates, Inc.) will be preparing the Historic Context entitled Changes in Hunter-Gatherer Mobility and Economic Strategies for Northeast Texas, and the Historic Context on Effects of European Contact on Native and Immigrant Indians in Northeast Texas will be prepared by Timothy $K$. Perttula (Texas Historical Commission). The final versions of these contexts will be completed by September 1, 1991. 